\title{
Social Impact of FATA Development Authority Skill Development Program in Khyber Agency
}

\author{
Akbar Jan*1, Shabana Gul², Muhammad Naeem ${ }^{3}$ \\ Institute of Management Sciences, Peshawar, Pakistan
}

\begin{abstract}
This study tries to investigate the assessment of the FATA Development Authority's skill development program offered for FATA youth. The aim is to explore the social impact of the FATA Development Authority's skill development program in Khyber Agency and to critically analyze the three main objectives of these programs which are: to impart new skill in the youth and to make them more competent, to increase the employability level of the youth and lastly to promote the entrepreneurial spirit in order to start their own business. The trainings were broadly divided into hard and soft skills trades, which were planned in more than 35 different trades and covered the entire FATA region. These trainings were also conducted in Khyber Agency in these different trades. Due to unavailability of data, confidentiality and loss of archival data, only 6 different trades with three each for hard and soft skills have been taken in Khyber Agency. Trainings for these trades were conducted in the financial year 2013-14 and 2014-15. The data have been collected through semi-structure interviews with the trainees and then it were analyzed descriptively. Total of 35 out of 51 trainees were interviewed for the study in selected trades. Finding of this study shows that only $26 \%$ of the trainees learned new skills, $20 \%$ of the trainees got employment or self-employed and $17 \%$ of trainees started their own business.
\end{abstract}

\section{Introduction}

\subsection{Background of the Study}

Federally Administered Tribal Areas is one of the less developed regions in Pakistan with literacy rate of $24.05 \%$; where the literacy rate for male is $36.66 \%$ and for female it is $10.50 \%$. The overall enrollment rate in Government Institutions is 600967 with $408638(68 \%)$ in Primary, 71150 (12\%) in Middle, 97746 (16\%) in High, $8565(1.4 \%)$ in Higher, while 14868 (2.5\%) are enrolled in colleges. There are total 5699 Government Educational Institutions in Federally Administered Tribal Areas (FATA) in which 4344 are functional, 1143 are nonfunctional and 197 are closed (Naseer, 2015). The details of Government institutions are illustrated in following table.

Low literacy rate and lack of skills are two of the reasons impeding development in the tribal region. Semi-literate and educated youth of FATA has no opportunity of acquiring skills which they can use as a means of getting employment or starting their own business. To address this issue, FATA Development Authority initiated the skill development program in 2007 for FATA region and these programs cover seven agencies (Khyber, Mohmand, Malakand, Orakzai, Kurram, South Waziristan, North Waziristan) and six FRs

*Corresponding author.

Email: akbarafride@gmail.com

http://www.jbrc.pk
(FR Peshawar, FR Kohat, FR Bannu, FR Lakki, FR DI Khan, FR Tank).

These programs were initiated with the following objectives:

1. To impart new skill in the FATA youth

2. Increase the level of employability

3. Encourage and promote entrepreneurship

These skill development programs had been fully functional since the date of its inception and more than 40,000 youth were trained in different trades under the skill development program. These skill development programs consisted of both soft skills and hard skills and were offered in more than 35 different trades. The details of both soft skills and hard skill trades are illustrated in Table 1.3.

FATA Development Authority offered the above trade under different heads like intuitional and field internship based, women Skills Development Centers in FATA, Skilling FATA through Joint Venture, Skill Development and Entrepreneurship Training Program. The detail of the number of trainees who completed their trainings under the different heads is given below.

Like other agencies, FATA Development Authority Skill Development Program also covers the Khyber Agency and youth is among of its major beneficiaries. 
Table 1.1: Total number of Government Educational Institute in FATA

\begin{tabular}{llccc}
\hline S.No & Level & \multicolumn{3}{c}{ Institution } \\
& & Boys & Girls & Total \\
\hline 1 & Mosque & 178 & - & 178 \\
2 & Primary & 2,114 & 1,613 & 3,727 \\
3 & Middle & 337 & 200 & 537 \\
4 & High & 257 & 75 & 332 \\
5 & Higher Secondary & 11 & 05 & 16 \\
6 & Degree College & 24 & 13 & 37 \\
7 & Elementary College & 03 & 01 & 04 \\
8 & Community & 360 & 451 & 811 \\
9 & IHC & - & 44 & 44 \\
10 & Government College of Management Sciences & 05 & - & 05 \\
11 & Government Technology Institute & 08 & - & 08 \\
\hline & Grand Total & $\mathbf{3 , 2 9 7}$ & $\mathbf{2 , 4 0 2}$ & $\mathbf{5 , 6 9 9}$ \\
\hline
\end{tabular}

Source: Annual statistical report of Government Educational Institutes (2013-14)

Table 1.2: Current Status of Government Educational Institutes in FATA

\begin{tabular}{llccc}
\hline S.No & Government Institute & Functional & Non Functional & Closed \\
\hline 1 & Government Primary Schools & 3,027 & 694 & 06 \\
2 & Mosque Schools & 124 & 53 & 01 \\
3 & Community Primary Schools & 374 & 247 & 190 \\
4 & IHC Schools & 37 & 07 & - \\
5 & Middle Schools & 445 & 92 & - \\
6 & High Schools & 291 & 41 & - \\
7 & Higher Secondary Schools & 14 & 09 & - \\
8 & Degree College & 28 & & - \\
9 & Elementary College & 04 & - & $\mathbf{1 9 7}$ \\
\hline
\end{tabular}

Source: Annual statistical report of Government Educational Institutes (2013-14)

Under the above mentioned different heads, a number of Khyber Agency youth has been trained under the umbrella of skill development program in different trades.

This study was conducted to explore the Social Impact of the FATA Development Authoritys Skill Development Programs in Khyber Agency in terms of achievement of its desired objectives, which are mentioned earlier. For this study different trades including both soft skills and hard skills have been selected on convenient basis. Data have been collected through semi-structure interview from the trainees who attended the training of different trades which are mentioned in Table 1.5. However, due to the confidentiality, loss of record and unavailability of the trainees the data have been collected from limited number of trainees ( 35 out of 51) for the selected trades. The details of selected trade and number of trainees are illustrated in following table.

The main objective of this study is to explore the social impact of the Skill Development Program in Khyber Agency in term of:

1. New skills learned by the trainees

2. Impact of trainings on the employability level of the trainees

3. The role of these trainings in promotion of en- 
Table 1.3: Current Status of Government Educational Institutes in FATA

\begin{tabular}{llcl}
\hline S.No & Trade & S.No & Trade \\
\hline 1 & Auto Electrician & 19 & Leather Goods \\
2 & Auto Mechanics & 20 & Light Engineering \\
3 & Block Mason & 21 & TV Camera \& Lightening Course \\
4 & Foot Ball Stitching & 22 & Computer Networking \\
5 & Gemology \& Carving & 23 & Video Post-Production \\
6 & Driving License with (LTV, HTV) & 24 & Heavy Machinery Operator \\
7 & X-Ray Machine Operator & 25 & Plumbing \\
8 & AC Refrigeration & 26 & Electrician \\
9 & Material Testing & 27 & Mobile Phone Repairing \\
10 & PLC Electronic & 28 & Land Surveying (With Auto CAD) \\
11 & Surveyor Civil & 29 & Office Automation and Management \\
12 & Computer (Hardware) & 30 & Laboratory Assistant \\
13 & Advanced Auto Mechanic (EFI/CNG) & 31 & Dress Making \& Tailoring Techniques \\
14 & Steel Fixer & 32 & Turner Machinist \\
15 & Fan Assembly Course & 33 & Mechanic-II (Chasis) \\
16 & Auto CAD 2-D, 3-D & 34 & Quantity Surveyor \\
17 & Hotel Management & 35 & Call Center Operator \\
18 & Camera \& Lightening & 36 & TV Direction/Production \\
\hline
\end{tabular}

Source: FATA Development Authority

Table 1.4: Detail of the Trainees up to financial year 2014-2015

\begin{tabular}{llc}
\hline S.No & Name of Scheme & Total No. of Trainees \\
\hline 1 & Skills Development Program (Institution-Based) & 16,300 \\
2 & Women Skills Development Centers in FATA & 16,282 \\
3 & Skilling FATA Through Joint Venture & 2,595 \\
4 & Skill Development and Entrepreneurship Training & 4,124 \\
5 & Skills Development Program (Field Internship) & 3,107 \\
\hline & Total Trainees & $\mathbf{4 2 , 4 0 8}$ \\
\hline
\end{tabular}

Source: FATA DA Annual Report 2014-2015

trepreneurship process

The Skill Development Program covers the entire FATA with focus on youth including both male and female. More than 35 different trades have been offered under this initiative and consisted of both hard and soft skills trainings. However, this research study is limited to Khyber agency and the data have been collected from male trainees only, due to cultural barriers, the female trainees did not participate in the study. On the basis of convenience and availability of data, six different trades have been selected for this study out of the total 35 trades. The selected trades include AC Refrig- eration, gemology, computer networking, hotel management, camera and lightening, TV direction and production.

\section{Literature Review}

Skill is the ability, coming from ones knowledge, practice and aptitude to perform something effectively (Aring et al., 2015). Skill is further divided into two types, one is called technical or hard skills and the other is called soft skills. Technical skill or hard skill is required to deal with tool or processes such as coding 
Table 1.5: Trade wise Trainees details

\begin{tabular}{llccc}
\hline S.No & Trade & Financial year & Trade Type & No. of total trainees \\
\hline 1 & AC Refrigeration & $2013-14$ & Hard Skill & 18 \\
2 & Gemology & $2014-15$ & Hard Skill & 11 \\
3 & Computer Networking & $2014-15$ & Hard Skill & 6 \\
4 & Hotel Management & $2014-15$ & Soft Skill & 4 \\
5 & TV Direction \& Production & $2014-15$ & Soft Skill & 4 \\
6 & Camera \& Lightening & $2014-15$ & Soft Skill & 8 \\
\hline \multicolumn{2}{c}{ Total Number } \\
\hline
\end{tabular}

Source: FATA Development Authority

software or operating a machine; while soft skill is the skill required for interaction with humans to get work done such as communication, human relation, negotiation and team work etc (Aring et al., 2015).

Previous research shows that skill development plays a vital role in sustainable economic growth of a country (Khan, 2009). Services sector is one of the growing sectors in Asian countries with high economic and social impact; where the modern services are technological and knowledge intensive in nature and it demands for high specialized skilled workforce (Jagannathan, 2013). Technological changes ultimately affected the job structure in the region and brought new challenges to the developing countries in South Asia (De Vries et al., 2016).

Skill development programs increase the competency level of workforce and provide better opportunities for career growth (Milberg and Winkler, 2011). According to 2005 International Labor Conference resolution, quality education, training and skill improve productivity and give a higher return in the form of income (Cichon, 2013). Research shows that youth equipped with market based skill has greater opportunities to find a good job; the skills show a positive impact on future employment and enable them to start their own business (Adams, 2012).

Skill development training of entrepreneurship shows a positive impact on the new start-up, it increases the number of youth Pre-entrepreneurs and employability (Schoof et al., 2006). There is strong evidence that training has a positive impact on the entrepreneurship processes, with improvement in management skill, giving birth to new ideas, empowering youth in decision making and enabling them to finance their own business (Day-Hookoomsing et al., 2003). However, entrepreneurship training alone has shown a mixed impact on the new start up or on the growth of existing business; it produces positive impact in some cases, while at the same time it produces a negative result in other cases (Patel, 2014).
The European Training Foundation (ETF) is a European agency which was established with the vision to develop an efficient Vocational Education Training (VET) for their member countries. It provides market based training to the workforce in order to enhance employability level of their workforce (Faludi and Waterhout, 2012). Countries are using different approaches towards the skill development of their workforce. The Republican of Korea has developed National Competency Standards (NCS) which identify the required standards of performance for a worker to perform in industrial setup. The aim of the National Competency Standard model is to make society competencyoriented rather than academic oriented and it comprises of both institutional and industrial based trainings (Kanchoochat et al., 2014).

People Republic of China initiated the National Revitalization Program for highly skilled personnel in order to strengthen team building skills in enterprises, and to conduct training programs targeting different skill levels of worker. The National Revitalization Program (NRP) is supported by the training subsidy and provides the training opportunities for employed and unemployed workforce. It was initiated in June 2012 with the aim to promote and encourage pre-job training and on-the-job training for new and existing skills up gradation (Kanchoochat et al., 2014). Government of India developed a frame work in 2014 in order to equip youth with market based skills, to increase their employability level, and to promote entrepreneurship. The skill development framework consists of apprentices Act, 1961, the National Skill Qualification Framework (NSQF) and the National Skill Policy (NSP). The apprentices Act 1961 made it mandatory for the employers to establish training infrastructure in order to ensure maximum access of trainees to real work environment through on-the-job training. In 2009, National Policy for skill development has been formulated with the aim to develop strategies for addressing the skills development challenges and to empower the work- 
force with market based knowledge and skill in order to make them globally competitive. The National Skill Qualification Framework (NSQF) is competency base system which organizes all qualification, based on level of knowledge, skills and aptitude (Kohli et al., 2015).

Bangladesh has developed National Skill Development Policy for the period of 2010-15 with the aim to develop their workforce and make them competent in international market. The objectives of the skills development policy include: the reorientation of the skill development initiatives with changing technologies and labor market demands, improving the productivity and profitability of enterprises, strengthening national competitiveness and to reduce poverty, improve the quality and relevance of skills development in Bangladesh, and to increase level of participation in skills development by employers. To achieve these objectives of the National Skill Development Policy the government of Bangladesh established the National Skill Development Council (NSDC) with the collaboration of their industrial partner. Based upon the National Skill Development Policy (NSDP) they have started to offer formal trainings under the vocational and technical training institutes and to impart informal trainings through on the job training or field internship basis (Mamun and Nath, 2010). The approaches of some countries towards skill development programs are illustrated in the following table.

In provision of skill development program, Pakistan lags behind the international and regional level. To address this issue, government of Pakistan established a new body, the National Vocational and Technical Education Commission (NAVTEC) in 2006. It provides policy direction for skill development program in order to make the workforce competent according the local and international market demand.

NAVTEC has developed National Skill Strategy (Ansari and $\mathrm{Wu}, 2013$ ):

- Provision of skill to the workforce based on the demand of industry

- Expending geographical provision of skill development program and to increase the equity and employability of workforce

- Assure the quality of the skill development program

To put National Skill Strategy (NSS) in action, FATA Development Authority on directions of Governor Khyber Pakhtunkhwa also initiated skill development program for FATA youth (Mirza et al., 2007). These trainings were offered for different trades like tailoring, machining, mining, MS office, building electrician, survey etc. The youth including both male and female from the seven agencies and six frontier regions are the main beneficiaries. Before 2014, FATA development Authority was providing these training to
1,700 trainees on annual basis, but later the number of trainees increased from 1,700 to 10,000.These skill development trainings were initiated with the aim to increase the employability and encourage the youth to start their own business FATA Development Authority Annual Report 2014-2015, 2014.

Though program design for skill development appears to be quite structured on paper and has clearly articulated goals. But, the real test is implementation of these programs and the achievement of their desired objectives. The common objectives of Skill development Program is to imparting new skills, increase level of employability and to encourage the youth to start their own business. This research is an assessment study which is conducted to explore the Social Impact of FATA Development Authoritys Skill Development Program in term of their desired objectives.

\section{Methodology}

\subsection{Research Design}

This is a qualitative research study and data were collected through semi-structured interviews from the trainees. On convenient sampling basis only six different trades have been selected out of the total 35 trades, with three each for hard skills and soft skills. The snow balling technique was also employed along with the convenient sampling in order to access maximum trainees. Limited number of trainees showed their willingness and interest to participate in the study for the above selected trades while some of the trainees were reluctant to participate.

\subsection{Population and Sample size}

In this study the data are collected from the Khyber Agency trainees who have completed their trainings in the financial year 2013-14 and 2014-15. A total of 51 trainees have completed their training for the selected trades, as shown in Table 3.1. However, only 35 trainees have shown their willingness to participate in this research study.

\subsection{Data Collection}

This study is based upon primary data, which were collected in two steps:

- From FATA Development Authority

- Through semi-structured interviews with the trainees 
Table 2.1: Approaches of countries towards skill development

\begin{tabular}{|c|c|c|c|c|}
\hline S.No & $\begin{array}{l}\text { Country } \\
\text { Name }\end{array}$ & Frame Work & Training Approaches & Target Group \\
\hline \multirow[t]{2}{*}{1} & $\begin{array}{l}\text { Republic of } \\
\text { Korea }\end{array}$ & NCS & Institution Based Training & Student \\
\hline & & & Industry Based Training & Employees \\
\hline \multirow[t]{2}{*}{2} & China & NRP & On-the-job & Fresh Graduates \\
\hline & & & National Revitalization Plan & Professionals \\
\hline \multirow[t]{2}{*}{3} & India & NSQF & Apprentice Training & Student \\
\hline & & & On-the-job Training & Professionals/Fresh \\
\hline \multirow[t]{2}{*}{4} & Bangladesh & NSDP & On the job Training & Informal Training \\
\hline & & & Vocational and Technical Training Institutes & Formal Training \\
\hline
\end{tabular}

Source: www.adb.org

\subsubsection{FATA Development Authority}

FATA Development Authority provides the relevant information related to skill development program and about the different trades they have offered for the FATA Youth. They have also provided the list of trainees with details who had completed their trainings in the financial year 2013-14 and 2014-15.

\subsubsection{Semi-structured Interviews with trainees}

The data have been collected from the trainees through semi-structured interview and each interview lasted for 10 minutes on average. A total of 35 out of the 51 trainees have participated and required data were recorded during the interviews. In interview, different topics were discussed like the impact of skill development program on new skill acquired, employability and entrepreneurship. The trainees also provided their suggestions for improvement of skill development program.

\section{Data analysis}

After collecting data and responses from the trainees on the three major research questions along with sub-questions, the data were converted into tabulated form. The data were descriptively analyzed and the results were summarized in the form of percentages against the each desired objectives of the FATA Development Authoritys skill development program.

This research study was carry on for selected 6 different trades out of the total 35 trades offered by the FATA Development Authority under the umbrella of skill development program. The selected six trades included three each for hard skill and soft skill. The trades and trainees wise detail of the selected trades are illustrated in the following table.

The relevant responses of the trainees have been discussed below:

Table 3.1: Trade wise Trainees details

\begin{tabular}{llccc}
\hline S.No & Trade & Financial year & $\begin{array}{c}\text { Total number } \\
\text { of trainees }\end{array}$ & $\begin{array}{c}\text { No. of trainees } \\
\text { participated }\end{array}$ \\
\hline 1 & AC Refrigeration & $2013-14$ & 18 & 11 \\
2 & Gemology & $2014-15$ & 11 & 08 \\
3 & Camera \& Lightening & $2014-15$ & 8 & 04 \\
4 & Computer Networking & $2014-15$ & 06 & 04 \\
5 & Hotel Management & $2014-15$ & 04 & 04 \\
6 & TV Direction \& Production & $2014-15$ & 04 & 04 \\
\hline & Total Number & & $\mathbf{5 1}$ & $\mathbf{3 5}$ \\
\hline
\end{tabular}

Source: FATA Development Authority 
Table 4.1: Trade wise Trainees details

\begin{tabular}{llccc}
\hline S.No & Trade & Financial year & $\begin{array}{c}\text { No. of total } \\
\text { trainees }\end{array}$ & $\begin{array}{c}\text { No. of trainees } \\
\text { Interviewed }\end{array}$ \\
\hline 1 & AC Refrigeration & $2013-14$ & 18 & 11 \\
2 & Gemology & $2014-15$ & 11 & 08 \\
3 & Camera \& Lightening & $2014-15$ & 08 & 04 \\
4 & Computer Networking & $2014-15$ & 06 & 04 \\
5 & Hotel Management & $2014-15$ & 04 & 04 \\
6 & TV Direction \& Production & $2014-15$ & 04 & 04 \\
\hline
\end{tabular}

Source: FATA Development Authority

\subsection{New skill acquisition}

In the interviews the question has been asked from the trainees about the new skill they have learned as a result of the training program. Only $26 \%(9 / 35)$ of the trainees have responded that they have learned new skills in the training. However, when asked about the practical demonstration only 20\% (7/35) replied that they can demonstrate these skills practically. $74 \%$ $(26 / 35)$ trainees replied that they have not acquired any new skills in the trainings offered by the FATA Development Authority. In general the AC Refrigeration and Gemology trades provided positive results and the trainees have acquired new skills in these two trades. The rest of the trades like camera \& lightening, computer networking, hotel management and TV production \& direction trades have showed disappointing results as mentioned in the Table 4.2 .

\subsection{Employability}

This research study shows that only $20 \%(7 / 35)$ of the trainees were employed after getting the trainings. Among those $20 \%$, the percentage of self-employed and employed is $86 \%(6 / 7)$ and $14 \%(1 / 7)$ respectively. Furthermore, the results also show that $80 \%(28 / 35)$ are still unemployed. The AC refrigeration and Gemology trades gave positive results as compared to the other trades and showed the level of employability or selfemployability as $36 \%(3+1 / 11)$ and $37 \%(3 / 8)$, respectively. The other trades like camera \& lightening, computer networking, hotel management, TV direction and production showed $0 \%$ of the employability level as illustrated in Table 4.3.

\subsection{Entrepreneurship}

Findings suggest that $17 \%(6 / 35)$ of the total trainees started their own business. The AC Refrigeration and Gemology trades showed positive results as compared to the other trades. From the above
$17 \%(6 / 35)$, the contribution of AC Refrigeration and Gemology trades was 50\% (3/6) and 50\% (3/6) respectively. The other trades like camera \& lightening, computer networking, hotel management and TV direction and production showed $0 \%$ contribution towards the self-employment or new start-ups. This study also shows that $83 \%(5 / 6)$ of the startups are still surviving, while $17 \%(1 / 6)$ failed to survive. The detail is illustrated in Table 4.4 .

\section{Conclusion and Discussion}

In the era of globalization and technology, skill development program is crucial for the sustainable economic growth. Effective and market based skill development programs can impart new skill in the workforce and enhance the competence in the market. These programs not only make the workforce competent but also increase the employability ratio and encourage trainees to start their own business (Mok, 2013). This study is an assessment study and aimed to critically analyze the skill development programs offered by FATA Development Authoritys for the youth of FATA and to explore their social impact in terms of new skill imparted, employability and entrepreneurship.

\subsection{New skill acquisition}

Research study reveals that skill development programs equip the work force with new skill and make them competent (Milberg and Winkler, 2011). Findings of this study show that $26 \%$ of the trainees believed that they have learned new skill through training. The AC Refrigeration and Gemology trades have shown positive results as compared to the other trades and the trainees reported to have learned new skills in these two trades. The results of the other trades, which include camera \& lightening, hotel management, computer networking and TV direction and produc- 
Table 4.2: New Skill Acquired

\begin{tabular}{llcccc}
\hline S.No & Trade & $\begin{array}{c}\text { No. of } \\
\text { trainees }\end{array}$ & $\begin{array}{c}\text { No. of trainees } \\
\text { new skill } \\
\text { acquired (No } \\
\text { practical } \\
\text { Demonstration) }\end{array}$ & $\begin{array}{c}\text { No. of trainees } \\
\text { new skill } \\
\text { acquired (with } \\
\text { practical } \\
\text { demonstration) }\end{array}$ & $\begin{array}{c}\text { No. of } \\
\text { trainees no } \\
\text { new skill } \\
\text { acquired/ } \\
\text { learned }\end{array}$ \\
\hline 1 & AC Refrigeration & 11 & 06 & 04 & 05 \\
2 & Gemology & 8 & 03 & 03 & 05 \\
3 & Camera \& Lightening & 4 & 0 & 0 & 04 \\
4 & Computer Networking & 4 & 0 & 0 & 04 \\
5 & Hotel Management & 4 & 0 & 0 & 04 \\
6 & TV Direction \& Production & 4 & 0 & 0 & 04 \\
\hline & Total Number & $\mathbf{3 5}$ & $\mathbf{0 9}$ & $\mathbf{0 7}$ & $\mathbf{2 6}$
\end{tabular}

Table 4.3: No of self-employed/employed/unemployed

\begin{tabular}{llcccc}
\hline S.No & Trade & $\begin{array}{c}\text { No. of } \\
\text { trainees }\end{array}$ & $\begin{array}{c}\text { No. self } \\
\text { employed }\end{array}$ & $\begin{array}{c}\text { No. of employed } \\
\text { unemployed }\end{array}$ & $\begin{array}{c}\text { No. of } \\
\text { unemplo }\end{array}$ \\
\hline 1 & AC Refrigeration & 11 & 03 & 01 & 07 \\
2 & Gemology & 08 & 03 & 0 & 05 \\
3 & Camera \& Lightening & 04 & 0 & 0 & 04 \\
4 & Computer Networking & 04 & 0 & 0 & 04 \\
5 & Hotel Management & 04 & 0 & 0 & 04 \\
6 & TV Direction \& Production & 04 & 0 & 0 & 04 \\
\hline
\end{tabular}

Table 4.4: New startup/self-employed

\begin{tabular}{|c|c|c|c|c|}
\hline S.No & Trade & $\begin{array}{l}\text { No. of } \\
\text { trainees }\end{array}$ & $\begin{array}{l}\text { No. of new start up } \\
\text { started by trainees }\end{array}$ & $\begin{array}{l}\text { No. of startup } \\
\text { still surviving }\end{array}$ \\
\hline 1 & AC Refrigeration & 11 & 03 & 02 \\
\hline 2 & Gemology & 08 & 03 & 03 \\
\hline 3 & Camera \& Lightening & 04 & 0 & - \\
\hline 4 & Computer Networking & 04 & 0 & - \\
\hline 5 & Hotel Management & 04 & 0 & - \\
\hline \multirow[t]{2}{*}{6} & TV Direction \& Production & 04 & 0 & - \\
\hline & Total Number & 35 & 06 & 05 \\
\hline
\end{tabular}

tion, are disappointing and according to the trainees they havent learned any new skills in these trades. The trainees of the AC Refrigeration and Gemology were found satisfied from the content of the training design and the way these trainings were delivered. Whereas, the trainees of the camera \& lightening, hotel manage- 
ment, computer networking and TV direction and production trades were unsatisfied from training content and expressed their concerns about the trainings in interviews. To impart new skills through training it is important to design training content effectively, based upon the market needs and demand while keeping the targeted trainees in focus. Besides the content design, it is also important to deliver the training effectively in a conducive environment.

\subsection{Employability}

Literature shows that there is a positive relation between skill development program and employability and it makes the workforce competent and helps them find a job (Adams, 2012). Skill development programs equip the trainees with new skill and ultimately increase the chances of their employability. However, skill development does not guarantee the employability and there are some other environmental factors which also affect employability. The results of the current study show that $20 \%$ of the total trainees were employed after receiving the skill development trainings. The AC Refrigeration and Gemology trades have shown positive results as compared to other trades. The percentage of the employability for AC Refrigeration and Gemology remained $36 \%$ and $37 \%$, respectively. Whereas, the other trades like computer networking, camera \& lightening, hotel management and TV direction \& production showed $0 \%$ of the employability level. The AC Refrigeration and Gemology trade have shown positive results because these were market based trainings and the local market has the potential to absorb the trainees of these trainings as well as these trades are less capital intensive. In contrast, there is limited or no potential in the local market to absorb the trainees of other trades like computer networking, hotel management, camera \& lightening and TV direction and production in the local market.

\subsection{Entrepreneurship}

There is a strong evidence that skill development programs encourage the youth to start their own business and promote the entrepreneurship process. It imparts entrepreneurial spirit in youth and makes them capable to manage and finance their business effectively (Adams, 2012). There is a positive relation between skill development training programs and the entrepreneurship and these programs give birth to the pre-entrepreneurs schoof2006. Skill development program has a mixed impact on the entrepreneurship processes (Patel, 2014). The findings of this research study show that after receiving the training in selected six different trades, $17 \%$ of the total trainees started their business or own startups. AC Refrigeration and Gemology have shown positive results with the percentage of the new startups of $27 \%(3 / 11)$ and $37 \%(3 / 8)$, respectively. Whereas, others trades did not make any contribution to entrepreneurship process. The AC Refrigeration and Gemology trade are market based and less capital intensive; therefore these are the factors which encourage the youth to start their own business.

\subsection{Recommendations}

This study shows that the market based trades like AC refrigeration and Gemology provide better results in the form of employability and entrepreneurship as compared to other trades for which there is a limited or no potential in the local market. Therefore, a detailed study is required to identify market based trades. Linkages with academia and industry can play a vital role in the identification and designing of these training. Academia can make its contribution to the skill development program based on latest research studies and they can provide their input in the form of designing training content, implementation, evaluation and follow up of the trainings. Besides, academia and industry have a strong knowledge about the local market demand; based on their recommendation an effective training can be designed. They can provide opportunities to the trainees in the form of field internship or job placement. Industry can also make a good contribution in the form of the designing training content and they can provide the real job environment to the trainees.

During the interview, the trainees expressed that six months training period is too short, and they demanded to extend the training period. The long duration will provide them the better opportunities to learn and to demonstrate their skill practically during the training. The study also shows that one year and more than one year training programs are more effective and produce better result as compared to the short courses. Most of the trainees did not start their own venture due to the unavailability of fund and suggested FATA Development Authority should provide funds sand loan facility on soft terms and condition. Availability of the fund is the main issue while starting a new business and the youth of FATA does not have many resources to finance their venture. FATA youth are the people with entrepreneurial spirit and they can take risk of starting their own business. Besides the loan facility it is also necessary to arrange the Rozgar Mela, etc. for the trainees in order to create more employment opportunities. For effective implementation of the training and achievement of the desired results, it is necessary to offer the follow up training on the basis of follow up record and remain in touch with the trainees. This type of activity will boost the morale of the trainees, as well as it will make them more competent. These follow up trainings must to be designed as development trainings which will prepare the trainees for the future challenges. 


\subsection{Limitations of the study}

Skill Development Program covers the entire FATA region which consists of seven agencies and six FRs, and these trainings are offered in more than 35 different trades. However, this study is only limited to Khyber Agency, and due to unavailability of data, confidentiality and loss of archival data, a limited number of trainees were interviewed for the selected 6 different trades out of total 35 trades. The respondents of this study were the male trainees only, who had completed their trainings in the financial year 2013-14 and 2014-15.

\section{References}

Adams, A. V. (2012). The role of skills development in overcoming social disadvantage. Background paper prepared for the education for all global monitoring report.

Ansari, B. and Wu, X. (2013). Development of pakistans technical and vocational education and training (tvet): An analysis of skilling pakistan reforms. Journal of Technical Education and Training, 5(2).

Aring, M. et al. (2015). ASEAN Economic Community 2015: Enhancing competitiveness and employability through skill development. ILO.

Cichon, M. (2013). The social protection floors recommendation, 2012 (no. 202): Can a six-page document change the course of social history? International Social Security Review, 66(3-4):21-43.

Day-Hookoomsing, P., Essoo, V., et al. (2003). Promoting female entrepreneurship in Mauritius: strategies in training and development. International Labour Office.

De Vries, G. J., Chen, Q., Hasan, R., and Li, Z. (2016). Skills and activity upgrading in global value chains: Trends and drivers for asia.

Faludi, A. and Waterhout, B. (2012). The making of the European spatial development perspective: No masterplan. Routledge.
Jagannathan, S. (2013). Education and skills in asia: Responding to greening economies. In Skills Development for Inclusive and Sustainable Growth in Developing Asia-Pacific, pages 265-280. Springer.

Kanchoochat, V., Intarakumnerd, P., et al. (2014). Tigers trapped: Tracing the middle-income trap through the east and southeast asian experience. WP , 4:2014.

Khan, S. H. (2009). Making people employable: Reforming secondary education in pakistan. The Pakistan Development Review, pages 603-617.

Kohli, S., Bandhopadhyay, M. R., and Kohli, M. K. (2015). Public private partnership in education an impactful means of promoting skill development and inclusive growth in india. Scholedge International Journal of Multidisciplinary E Allied Studies ISSN 2394-336X, 2(5):21-35.

Mamun, K. A. and Nath, H. K. (2010). Workers' migration and remittances in bangladesh. Journal of Business Strategies, 27(1):29.

Milberg, W. and Winkler, D. (2011). Economic and social upgrading in global production networks: Problems of theory and measurement. International Labour Review, 150(34):341-365.

Mirza, U. K., Ahmad, N., Majeed, T., and Harijan, K. (2007). Wind energy development in pakistan. Renewable and Sustainable Energy Reviews, 11(9):2179-2190.

Mok, K. H. (2013). The quest for an entrepreneurial university in east asia: impact on academics and administrators in higher education. Asia Pacific Education Review, 14(1):1122.

Naseer, N. (2015). Federally administered tribal areas (fata): Impacts of militarization and war crimes on tribal women and children. Pakistan Journal of Criminology, 7(4):129.

Patel, P. (2014). Effectiveness of entrepreneurship development interventions for women entrepreneurs: An ilo-wed issue brief.

Schoof, U. et al. (2006). Stimulating youth entrepreneurship: Barriers and incentives to enterprise start-ups by young people. Technical report, International Labour Organization. 